\title{
Kreativitas Guru dalam Mengembangkan Potensi Kognitif Siswa pada Pembelajaran PAI
}

\author{
1St. Aisyah, ${ }^{2}$ St. Marwiyah \\ 1,2 Program Studi Pendidikan Agama Islam, FTIK, IAIN Palopo \\ E-mail: aisyah.iainpalopo@gmail.com
}

\begin{abstract}
This study aims to: describe what creativity and effort should be done by teachers in developing cognitive potential. This research is a descriptive study, using a qualitative approach. Data collection is done by making observations, in-depth interviews, and documentation. Subjects and objects in this study were teachers of Palopo Muhammadiyah Middle School, Analysis and data processing were carried out in a qualitative manner. The research results obtained are, 1) Teachers carry out learning activities both in the classroom and outside the classroom, Utilizing learning media well and adjusting between learning materials with learning methods. 2) In developing the cognitive potential of students in learning PAI the teacher always strives to create a conducive atmosphere so that students do not feel bored in the learning process takes place, and conduct evaluations at the end of each lesson then provide reinforcement for students who answer the questions posed, make personal approaches and give appreciation to students. The implication of the implementation of teaching techniques carried out by PAI teachers has an impact on the success or failure of PAI learning, especially in developing the cognitive potential of grade VII A students in Palopo Muhammadiyah Middle School.
\end{abstract}

Keywords: Teacher Creativity, Cognitive Potential

\begin{abstract}
Abstrak
Penelitian ini bertujuan untuk: mendiskripsikan kreativitas dan upaya apakah yang harus di lakukan guru dalam mengembangkan potensi kognitif. Penelitian ini merupakan penelitian deskriptif, dengan menggunakan pendekatan kualitatif. Pengumpulan data dilakukan dengan mengadakan pengamatan (observasi), wawancara mendalam (interview), dan dokumentasi. Subjek dan objek dalam penelitian ini adalah guru SMP Muhammadiyah Palopo, Analisis dan pengolahan data dilakukan dengan cara kualitatif. Hasil penelitian yang diperoleh yaitu, 1) Guru melaksankan kegiatan pembelajaran baik di dalam kelas maupun di luar kelas, Memanfaatkan media pembelajaran dengan baik dan menyesuaikan antara materi pembelajaran dengan metode pemebelajaran. 2) Dalam mengembangkan potensi kognitif siswa dalam belajar PAI guru senantiasa mengupayakan menciptakan suasana yang kondusif agar siswa tidak merasa bosan dalam proses pembelajaran berlangsung, dan melakukan evaluasi setiap akhir pelajaran kemudian memberikan penguatan bagi siswa yang menjawab pertanyaan yang diajukan, melakukan pendekatan personal dan memberikan penghayatan kepada siswa. Implikasi pelaksanaan penerapan teknik mengajar yang dilakukan guru PAI berdampak pada berhasil tidaknya pembelajaran PAI khususnya dalam menngembangkan potensi kognitif siswa kelas VII A di SMP Muhammadiyah Palopo.
\end{abstract}

Kata Kunci: Kreativitas Guru, Potensi Kognitif. 


\section{Pendahuluan}

Kreativitas guru juga berpengaruh terhadap potensi siswa dari minat, semangat, penerimaan materi akan memunculkan hasil dari pengetahuan yang mereka dapatkan. Karena walaupun murid tersebut diajarkan beberapa kali dengan materi yang sama tapi dalam keadaan mengantuk, kurang semangat disebabkan karena guru kurang kreatif dalam mengajar, tidak akan mudah memahami meteri yang disampaikan. Kreativitas seorang guru sangat berperan aktif dalam proses pembelajaran, bagaimana menciptakan suasana belajar yang efisien dan efektif sehingga menghasilkan hal - hal yang diinginkan terkait dalam penelitian ini adalah pengembangan potensi kognitif siswa.

Untuk mengetahui kecerdasan seseorang adalah dilihat dari sejauh mana ia mampu menguasai materi yang telah diajarkan. Untuk mencapai hal tersebut diperlukan peran guru, saat ini kreativitas mengajar guru PAI sangat dibutuhkan dalam hal ini bagaimana guru mampu mengembangkan potensi kognitif siswa.

Perkembangan potensi kognitif siswa merupakan suatu hal yang penting di ketahui oleh guru sehingga pembelajaran yang di suguhkan penuh dengan kebermaknaan. Kognitif berarti persoalan yang menyangkut kemampuan untuk mengembangkan rasional (akal). Teori kognitif lebih menekankan bagaimana proses atau upaya untuk mengoptimalkan kemampuan aspek rasional yang dimiliki oleh orang lain. Oleh sebab itu, kognitif berbeda dengan teori behavioristik, yang lebih menekankan pada aspek kemampuan perilaku yang diwujudkan dengan cara kemampuan merespon terhadap stimulus yang datang kepada dirinya.

\section{Kerangka Teoretis}

Ramayulis mengatakan bahwa "Pendidik atau guru secara umum dijelaskan bahwa orang yang melakukan bimbingan . Pengertian ini memberi 
kesan bahwa pendidik adalah orang yang melakukan kegiatan dalam pendidikan". ${ }^{1}$

Pengertian guru menurut UUD No.14 Tahun 2005 pasal 1 ayat 1 dijelaskan bahwa:

Guru adalah pendidik profesional dengan tugas utama mendidik, mengajar, membimbing, mengarahkan, melatih, menilai, dan mengevaluasi peserta didik pada pendidikan anak usia dini jalur pendidikan formal, pendidikan dasar, dan pendidikan menengah. ${ }^{2}$

Di dalam literatur pendidikan Islam pendidik biasanya disebut sebagai berikut:

a. Ustadz yaitu seorang guru dituntut untuk komitmen terhadap profesinya, ia selalu berusaha memperbaiki dan memperbaharui model - model atau cara kerjanya sesuai dengan tuntutan zaman.

b. Mu'allim, berasal dari kata dasar ilmu yang artinya menangkap hakekat sesuatu. Ini mengandung makna bahwa guru adalah orang yang dituntut untuk menjelaskan hakekat dalam pengetahuan yang diajarkannya.

c. Murabby berasal dari kata dasar "rabb". Tuhan sebagai Rabb al-'alamin dan Rabb al-Nas yakni yang menciptakan, mengatur dan memelihara alam seisinya termasuk manusia. Dilihat dari pengertian ini maka guru adalah orang yang mendidik agar mampu berkreasi, sekaligus mengatur dan memelihara hasil kreasi untuk tidak menimbulkan mala petaka bagi dirinya, masyarakat dan alam sekitarnya.

d. Musyrid yaitu seorang guru yang berusaha menularkan penghayatan (transinternalisasi ) akhlak dan ataupun kepribadian kepada peserta didiknya.

e. Mudarris berasal dari kata darasa-yadrusu-darsan wadurusan wadirasatann yang berarti terhapus, hilang bekasnya, menghapus, melatih dan mempelajari. Artinya guru adalah orang yang berusah mencerdaskan peserta didiknya menghilangkan ketidaktahuan atau memberantas kebodohan serta melatih keterampilan peserta didik sesuai dengan bakat dan minatnya. 2005), h.49.

${ }^{1}$ Ramayulis, Metodologi Pendidikan Agama Islam, (Cet.IV; Jakarta: Kalam Mulia,

2Kompetensi guru, http://kompetensi.info/kompetensi-guru/definisi-gurumenurut-undang-undang.html, Tgl. 30 Agustus 2015 
f. Muaddih berasal dari kata $a d a b$, yang berarti moral, etika dan adab. Artinya guru adalah orang yang beradab sekaligus memiliki peran dan fungsi untuk membangun peradaban ( civilization ) yang berkualitas dimasa depan. Di Indonesia pendidik di sebut juga guru ( orang yang digurui dan ditiru ). ${ }^{3}$

Pengertian di atas adalah pengertian guru secara umum, sedangkan pengertian guru Agama Islam adalah orang yang melaksanakan bimbingan terhadap peserta didik secara Islami, dalam suatu situasi pendidikan Islam untuk mencapai tujuan yang diharapkan sesuai dengan ajaran Islam. ${ }^{4}$ Sebagai pengarah belajar (disector of learning), pendekatan yang digunakan dalam proses pembelajaran tidak hanya melalui pendekatan inrtuktional, akan tetapi disertai dengan pendekatan pribadi. Melalui pendekatan ini diharapkan guru dapat mengenal dan memahami siswa secara lebih mendalam sehingga dapat membantu dalam keseluruhan proses belajar.

Sri Minarti mengatakan bahwa guru merupakan fokus kunci (key focus) dalam mencapai tujuan pendidikan. Hal ini berarti bahwa pendidik adalah sebuah profesi yang menuntut keahlian, tanggung jawab, dan kesetiaan. Suatu profesi tidak dapat dilakukan oleh sembarang orang yang tidak di latih atau dipersiapkan untuk itu. Suatu profesi umumnya berkembang dari pekerjaaan yang kemudin makin matang serta ditunjang oleh tiga hal, yaitu keahlian, komitmen, dan keterampilan, yang membentuk segitiga sama sisi yang di tengahnya terletak profesionalisme. ${ }^{5}$ Dengan perkataan lain oleh Tohirin mengemukakan bahwa sebagai director of lerning, guru sekaligus berperan sebagai pembimbing dalam proses belajar mengajar, sebagai pembimbing seorang mahasiswa calon guru atau guru diharapkan mampu untuk :

${ }^{3}$ Muhaimin, "Wacana Pengembangan Pendidikan Islam" dalam Ramayulis, Metodologi Pendidikan Agama Islam, ( Ed. Revisi, Cet.IV; Jakarta: Kalam Mulia, 2005) , h. 49 50 .

${ }^{4}$ Ramayulis, Metodologi Pendidikan Agama Islam, op.cit., h. 50.

${ }^{5}$ Sri Minarti, Ilmu Pendidikan Islam Fakta Teoritis - Filosofis dan Aplikatif - Normatif, (Cet. I; Jakarta: Amzah, 2013), h. 108. 
1. Mengenal dan memahami setiap siswa baik secara individual maupun kelompok.

2. Memberikan informasi yang diperlukan dalam proses belajar mengajar.

3. Memberikan kesempatan yang memadai agar setiap siswa dapat belajar sesuai dengan karakteristik pribadinya.

4. Membantu setiap siswa dalam menghadapi masalah - masalah pribadi yang dihadapinya.

5. Menilai keberhasilan setiap langkah kegiatan yang telah dilakukannya. ${ }^{6}$

Sebagai seorang guru, untuk mencapai keberhasilan dari mengajar dapat dilihat dari keberhasilan seorang siswa dalam menerima pelajaran baik dari potensi Kognitif, Apektif maupun Psikomotoriknya. Sebagai seorang guru seharusnya tidak hanya memperhatikan mata pelajaran yang ia ajarkan akan tetapi juga melihat dari kepribadian atau karakteristik siswa. Potensi kognitif setiap siswa memang penting untuk diperhatikan karena itu guru harus kreatif bagaimana cara mengembangkan potensi tersebut kepada peserta didik kemudian mengimplementasikannya dalam kehidupan sesuai dengan Syari'at Islam.

Kreativitas guru merupakan istilah yang banyak di gunakan, baik di lingkungan sekolah maupun luar sekolah. Pada umumnya orang menghubungkan kreativitas dengan produk - produk kreasi. Dengan kata lain produk - produk kreasi itu merupakan hal yang penting untuk menilai kreativitas. Clark Monstakos seorang psikologi humanistis menyatakan bahwa kreativitas adalah pengalaman mengekspresikan (mengaktualisasikan) identitas individu dalam bentuk terpadu dalam hubungan dengan diri sendiri, dengan alam dan orang lain. ${ }^{7}$

Sofyan S.Willis mengatakan bahwa sifat kreatif membantu manusia telepas dari kesulitan. Karena dia bisa menciptakan sesuatu yang dinilai oleh masyarakat mengembangkan sesuatu, seperti membuat jalan tembus yang

\footnotetext{
${ }^{6}$ Tohirin, Psikologi Pembelajaran Pendidikan Agama Islam, (Cet. III; Jakarta: Raja Grafindo Persada, 2005), h. 79.

7 Munandar Utami, Kreativitas dan Keterbakatan Startegi Mewujudkan Potensi Kreatif dan Bakat, Gramedia Pustaka, ( Jakarta : 2002 ), h. 24.
} 
dekat ke kota dari kampungnya. Membuat semacam alat yang dapat membantu masyarakat. ${ }^{8}$

Abdul Rahman Shaleh dan Muhbid Abdul Wahab mengatakan bahwa kreativitas adalah suatu kemampuan untuk memecahkan persoalan yang memungkinkan orang tersebut memecahkan ide yang menghasilkan suatu yang adaptis (fungsi kegunaaan) yang secara penuh berkembang. ${ }^{9}$

Sebagaimana dikutip oleh Nur Kholis dalam Cece Wijaya dan Tabrani Rusyan, kreativitas biasanya diartikan sebagai kemampuan untuk menciptakan suatu produk baru, baik yang benar-benar baru sama sekali maupun yang merupakan modifikasi atau perubahan dengan mengembangkan hal-hal yang sudah ada. ${ }^{10}$

Kreativitas dibentuk dari dari berbagai dorongan seperti dari dalam diri individu (motivasi intrinsik) maupun dorongan dari luar atau lingkungan (motivasi ekstrinsik). Dorongan demi mewujudkan potensi diri seseorang untuk berkembang dan menjadi matang, dorongan untuk mengungkapkan dan mengaktifkan semua kapisitas seseorang merupakan motivasi primer untuk kreativitas ketika individu membentuk hubunganhubungan baru dengan lingkungannya. ${ }^{11}$

Nur Kholis mengatakan bahwa Kreativitas tidak hanya selamanya penemuan - penemuan baru akan tetapi bisa berangkat dari sesuatu yang sudah ada sebelumnya kemudian dikombinasikan dengan sesuatu yang lain. Atau kreativitas juga tidak harus berdasarkan kepada sesuatu yang belum

${ }^{8}$ Sofyan S.Willis, Psikologi Pendidikan, (Cet.I; Bandung:Alfabeta,c.v, 2012), h.157.

${ }^{9}$ Abdul Rahman Shaleh dan Muhbid Abdul Wahab, Psikologi Suatu Pengantar: Dalam Persfektf Islam, ( Cet. II, Jakarta: Kencana 2005 ), h.201.

${ }^{10}$ Cece Wijaya, \& A. Tabrani Rusyan., " Kemampuan Dasar Guru dalam Proses Belajar Mengajar, " dalam Nur Kholis, Pengaruh Kreatifitas Guru dalam Mengajar terhadap Minat Belajar Rumpun PAI siswa kelas V di MI NU Ngadiwarno Sukorejo Kendal, Srata 1 , ( Semarang: IAIN Walisongo, 2012 ), h. 18.td.

11 Muhammad Ihsan, "Pengaruh Metakognisi Dan Motivasi Terhadap Kemampuan Pemecahan Masalah Matematika Melalui Kreativitas Siswa Kelas VIII SMP Negeri Di Kecamatan Kindang Kabupaten Bulukumba," Jurnal Pendidikan Matematika Dan Ilmu Pengetahuan Alam 4, no. 2 (2016): 129-40, https://doi.org/10.18848/14479494/CGP/v15i03/45692.1. 
pernah diketahui orang lain kemudian mempraktekkannya akan tetapi kreativitas bisa juga diartikan segala sesuatu yang dilakukan apakah itu sudah diketahui sebelumnya atau tidak dan bisa menghasilkan sesuatu yang bermanfaat. $^{12}$

Berdasarkan keterangan di atas maka penulis dapat menyimpulkan bahwa kreativitas adalah usaha yang dilakukan baik yang belum ada sebelumnya maupun sudah ada sebelumnya yang dilakukan oleh seseorang sehingga menghasilkan manfaat sesuai dengan apa yang diharapkan. Misalnya seorang guru PAI ingin anak didiknya berhasil dalam belajar PAI maka guru PAI tersebut seyogianya memikirkan apa saja yang harus dilakukan untuk mencapai hal tersebut. Kreativitas guru dalam proses pembelajaran sangat dibutuhkan. Guna untuk mencapai tujuan pendidikan dan keberhasilan seorang guru dalam mengajar. Karena itu, dibutuhkan pengetahuan mengenai ciri - ciri guru kreatif yang bisa dijadikan sebagai contoh ketika dalam proses pembelajaran.

Neisser dikutip oleh Muhibbin Syah dalam Tohirin mengatakan bahwa istilah kognitif ( cognitive ) berasal dari kata cognition yang kesamaan katanya knowing, yang artinya mengetahui. Sedangkan dalam arti luas, cognition ( kognisi ) adalah perolehan, penataan, dan penggunaan pengetahuan. Secara sederhana, dapat dipahami bahwa kemampuan kognitif adalah kemampuan yang di miliki anak berfikiran lebih kompleks, serta kemampuan penalaran dan pemecahan masalah. ${ }^{13}$ Chaplin dalam Tohirin mengatakan bahwa Potensi kognitif sebagai salah satu domain atau ranah Psikologi manusia meliputi

12 Nur Kholis, Pengaruh Kreatifitas Guru dalam Mengajar Terhadap Minat Belajar Rumpun PAI Siswa Kelas V di MI NU Ngadiwarno Sukorejo Kendal, Strata 1, ( Semarang: IAIN Walisongo, 2012 ), h. 16.td.

13 Neisser dikutip dalam Muhibbin Syah, "Psikolgi Pendidikan Suatu Pendekatan Baru, “ dalam Tohirin, Psikologi Pembelajaran Pendidikan Agama Islam: Berbasis Integrasi dan Kompetensi, ( Ed.1. Cet.II; Jakarta : Raja Grafindo Persada, 2005), h. 48. 
setiap perilaku mental dan berhubungan dengan pemahaman, pertimbangan, pengolahan informasi, pemecahan masalah, kesenjangn, dan keyakinan. ${ }^{14}$

Berdasarkan makna di atas Tohirin menyimpulkan perkemabngan kognitif atau cognitive development, yakni perkembangan fungsi inlektual atau proses perkembangan kemampuan atau kecerdasan otak anak. ${ }^{15}$

2. Enam Garapan Potensi Kognitif

Menurut Ramayulis Potensi kognitif ini mencakup enam garapan, yaitu: ${ }^{16}$

\section{a. Knowledge ( pengetahuan )}

Kemampuan mengingat ( recall) konsep - konsep yang khusus dan yang umum, metode dan proses serta struktur. Benyamin Bloom dalam bukunya yang berjudul Taxonomi, of Educational Objektives, Book I Cognitif Domain, dalam Nana Sudjana mengatakan bahwa aspek kognitif pemahaman hafalan ( knowledge ) dimaksudkan sebagai cakupan dalam pengetahuan hafalan termasuk pada pengetahuan yang sifatnya faktual, disamping pengetahuan mengenai hal - hal yang perlu diingat kembali seperti pasal, ayat, rumus dan lain - lain. ${ }^{17}$ Ada beberapa cara untuk dapat menguasai / menghafal misalnya dibaca berulang - ulang, menggunakan teknik mengingat ( memo teknik ). Namun demikian walaupun tipe hasil belajar ini adalah tipe terendah diantara tipe belajar yang lain, tetapi tipe ini

14J.P. Chaplin, "Dictionory of Psychology" dalam Tohirin., Psikologi Pembelajaran Pendidikan Agama Islam: Berbasis Integrasi dan Kompetensi, ( Ed.I, Cet. II: Jakarta:PT. RajaGrafindo Persaada 2006), h.48-49.

15Tohirin, Psikologi Pembelajaran Pendidikan Agama Islam: Berbasis Integrasi dan Kompetensi, ( Cet.II; Jakarta : Raja Grafindo Persada, 2005), h. 49.

16 Ramayulis, Metodologi Pendidikan Agama Islam, op.cit., h. 24-25.

17 Benyamin Bloom, “Taxonomi, of Educational Objektives, Book I Cognitif Domain, “dalam Nana Sudjana, Dasar - dasar Proses Belajar Mengajar, (Cet. XII; Bandung: Sinar Baru Algensindo, 2011), h.50. 
adalah jembatan untuk melangkah ke jenjang tipe yang lebih tinggi yakni pengamalan atau pengaplikasian. ${ }^{18}$

b. Comprehension ( pemahaman )

Kemampuan memahami tanpa mengetahui hubungan - hubungannya dengan yang lain, juga tanpa kemampuan mengaplikasikan pemahaman tersebut. Nana Sudjana mengatakan bahwa tipe hasil belajar pemahaman lebih tinggi satu tingkat dari tipe hasil belajar pengetahuan hafalan. Pemahaman memerlukan kemampuan menangkap makna atau arti dari sesuatu konsep. Untuk itu, maka diperlukan adanya hubungan atau pertautan antara konsep dengan makna yang ada dalam konsep tersebut. ${ }^{19}$ c. Aplication ( aplikasi )

Kemampuan menggunakan konsep - konsep abstrak pada objek objek khusus dan konkret. Konsep abstrak tersebut bisa berupa ide - ide umum, prosedur prinip - prinsip teknis, atau teori yang harus diingat dan diaplikasikan. Sedangkan Nana Sudjana mengatakan bahwa aplikasi adalah kesanggupan menerapkan, dan mengaptraksi suatu konsep, ide, rumus, hukum dalam situasi yang baru. Misalnya memecahkan persoalan dengan menggunakan rumus tertentunya. Misalnya, memecahka persoalan dengan mengunakan rumus tertentu, menerapkan suatu dalil atau hukum dalam suatu persoalan. Jadi, dalam aplikasi harus ada konsep, teori, hukum, dan rumus. Dalil hukum tersebut, diterapkan dalam pemecahan suatu masalah ( situasi tertentu ). Denga perkataan lain, aplikasi bukan keterampilan motorik tapi lebih banyak keterampilan mental. ${ }^{20}$

d. Analysis ( analisis )

Kemampuan memahami dengan jelas hirarki ide - ide dalam suatu

18 Nana Suadjana, Dasar - dasar Proses Belajar Mengajar, ( Cet. XII; Bandung: Sinar Baru Algensindo, 2001 ). h. 50.

19Ibid., h. $50-51$.

${ }^{20}$ Ibid., 51. 
unit bahan atau membuat keterangan yang jelas tentang hubungan antara ide yang satu dengan ide yang lainnya. Analisis ini memperjelas bahan - bahan yang dipelajari dan menjelaskan bagaimana masing - masing ide itu berpengaruh.

\section{e. Syinthesis ( sintesis )}

Kemampuan merakit bagian - bagian menjadi satu keutuhan. Kemampuan ini melibatkan proses penyusunan, penggabungan bagian bagian untuk dijadikan suatu keseluruhan yang bersturkur yang semula belum jelas. $^{21}$ Semakna dengan pendapat Nana Sudjana yang mengatakan bahwa sintesis adalah lawan analisis. Bila pada analisis tekanan pada kesanggupan menguraikan suatu integrasi menjadi bagian yang bermakna, pada sintesis adalah kesanggupan menyatukan unsur atau bagian menjadi satu integritas. ${ }^{22}$ f. Evaluation ( evaluasi )

Kemampuan dalam mempertimbangkan nilai bahan dan metode yang digunakan dalam menyelesaikan suatu problem, baik bersifat kuantitatif dan kualitatif.

Jadi, Pengembangan potensi kognitif dalam tulisan ini dimaksudkan bahwa bagaimana pengembangan peserta didik dalam pembelajaran, dan ini bisa dilihat dari hasil belajar yang di capai.

\section{Metode dan Hasil Penelitian}

Penelitian ini adalah penelitian deskriptif kualitatif di mana dalam penelitian ini, mencoba untuk meneliti dan mendiskripsikan bagaimana kreativitas guru dalam mengembangkan potensi kognitif siswa kelas VII A pada pembelajaran PAI di SMP Muhammadiyah Palopo.

Adapun yang bertindak sebagai subjek penelitian dalam penelitian ini yakni siswa kelas VII A di SMP Muhammadiyah Palopo dan satu orang guru PAI yang mengajar di kelas VII A di SMP Muhammadiyah Palopo

${ }^{21}$ Ramayulis, Metodologi Penddikan Agama Islam, op.cit., h. 25

${ }^{22}$ Nana Sudjana, Dasar - dasar Proses Belajar Mengajar, op.cit., h. 52 
Hasil penelitian menunjukkan Kreativitas guru dalam mengembangkan potensi kognitif siswa yang dilakukan oleh guru PAI sangat di perhatikan. Ini dapat di lihat dari perlakuan yang di berikan oleh seorang guru PAI yang mengajar di kelas VII A yakni lebih sering memberikan tugas harian.

Dengan pemberian tugas tersebut sehingga siswa mampu mengingatkembali materi ajar yang telah di laksanakan sebelumnya, selain itu menyuruh siswa untuk merangkum materi yang telah dibahas.Walaupun masih menggunakan teknik yang sederhana tetapi siswa tetap aktif dalam melaksanakan tugas-tugas yang telah diberikan, terbukti dari hasil ulangan harian siswa rata-rata mendapatkan hasil 7.00 ke atas. Demikian yang dikatakan oleh Ibu Nursy Qadariah sebagai guru mata pelajaran PAI SMP Muhammadiyah Palopo. ${ }^{23}$

Menurutnya teknik yang beliau terapkan yakni pemberian PR ( Pekerjaan Rumah ) atau Tugas Harian dapat mengembangkan potensi kognitif siswa dengan alasan yakni: Karena melihat dari rata-rata nilai ketuntasan siswa lebih baik dan selain itu siswa lebih aktif dalam mengerjakan tugastugas yang diberikan.Guru juga melaksanakan kegiatan pembelajaran PAI di Mushallaah SMP Muhammaadiyah Palopo dengan alasan agar siswa lebih santai tidak merasa tegang dan agar lebih mudah memahami materi yang disampaikan.

Selain kreativitas yang dilakukan beliau juga mempunyai teknik tersendiri dalam mengajar. Berikut jawaban beliau ketika peneliti melakukan wawancara berkaitan dengan hal tersebut:

Teknik yang digunakan dalam pelaksanaan pembelajaran PAI, memberikan sesuatu hal yang berbeda dari tiap-tiap materi yang diajarkan. Memberikan

${ }^{23}$ Sumber Data :Nursy Qadariah, Guru Pendidikan Agama Islam, HasilWawancara, SMP MuhammadiyahPalopo, 10 Juni 2014. 
penghayatan kepada siswa, dan memberikan kepada siswa kesempatan dalam mengembangkan dan memahami materi yang telah diberikan. ${ }^{24}$

Dengan kreativitas mengajar yang dilakukan oleh seorang guru PAI sangat bermanfaat dan berperan penting dalam pembelajaran PAI baik bagi guru maupun untuk siswa SMP Muhammadiah Palopo.

Yang harus dilakukan seorang guru dalam mengembangkan Potensi Kognitif siswa Kelas VII A dalam belajar PAI di SMP Muhammadiyah Palopo yakni melakukan evaluasi kepada siswa. Hal ini dilakukan untuk mengetahui tingkat potensi kognitif kemampuan pada setiap siswa. ${ }^{25}$ Demikian menurut Ibu Nursy Qadariah.

Beliau juga menambahkan bahwa untuk meningkatkan potensi kognitif siswa maka yang dilakukan adalah dengan melakukan refiew terlebih dahulu sebelum melanjutkan materi selanjutnya. Guru juga harus menguasai materi yang akan diajarkan dan melakukan metode pemebelajaran yang sesuai dengan materi ajar.

Dalam hal ini berkaitan dengan teknik mengajar guru, yakni dapat dilihat dari hasil wawancara yang dilakukan oleh peneliti. Teknik yang digunakan dalam pelaksanaan pembelajaran PAI, memberikan sesuatu hal yang berbeda dari tiap-tiap materi yang diajarkan. Memberikan penghayatan kepada siswa, dan memberikan kesempatan kepada siswa dalam mengembangkan dan memahami materi yang telah diberikan. ${ }^{26}$

\section{Penutup}

Hasil penelitian penulis menyimpulkan sebagai berikut:

\footnotetext{
${ }^{24}$ Sumber Data :Nursy Qadariah, Guru Pendidikan Agama Islam, Hasil Wawancara, SMP Muhammadiyah Palopo, 10 Juni 2014.

${ }^{25}$ Sumber Data :Nursy Qadariah, Guru Pendidikan Agama Islam, Hasil Wawancara, SMP Muhammadiyah Palopo, 10 Juni 2014.

${ }^{26}$ Sumber Data : Nursy Qadariah, Guru Pendidikn Agama Islam, Wawancara, SMP Muhammadiyah Palopo.
} 
Guru melaksankan kegiatan pembelajaran baik di dalam kelas maupun di luar kelas, misalnya di Mushallah SMP Muhammaadiyah Palopo, dan di perpustakaan, dengan tujuan mengurangi rasa jenuh kepada siswa dalam belajar PAI juga menciptakan suasana belajar yang efektif dan menyenangkan.Memanfaatkan media pembelajaran dengan baik dan menyesuaikan antara materi pembelajaran dengan metode pemebelajaran. Dalam mengembangkan potensi kognitif siswa dalam belajar PAI guru senantiasa mengupayakan menciptakan suasana yang kondusif agar siswa tidak merasa bosan dalam proses pembelajaran berlangsung, dan melakukan evaluasi setiap akhir pelajaran kemudian memberikan penguatan bagi siswa yang menjawab pertanyaan yang diajukan, melakukan pendekatan personal dan memberikan penghayatan kepada siswa.

\section{Daftar Pustaka}

Departemen agama RI, al-Qur'anul Karim dan Terjemahannya. Jakarta: Yayasan Penyelenggara Penerjemah al-Qur'an, 2008.

Ihsan, Muhammad. "Pengaruh Metakognisi Dan Motivasi Terhadap Kemampuan Pemecahan Masalah Matematika Melalui Kreativitas Siswa Kelas VIII SMP Negeri Di Kecamatan Kindang Kabupaten Bulukumba." Jurnal Pendidikan Matematika Dan Ilmu Pengetahuan Alam 4, no. 2 (2016): 129-40. https://doi.org/10.18848/14479494/CGP/v15i03/45692.1.

Kholis, Nur. Pengaruh Kreatifitas Guru dalam Mengajar terhadap Minat Belajar Rumpun PAI siswa kelas V di MI NU Ngadiwarno Sukorejo Kendal, Srata 1. Semarang: IAIN Walisongo, 2012.

M. Attar, Semi, Sopan Santun Berbicara Dan Menyimak, Bandung: Titian ilmu,1998.

Maskawai, Ibnu, Menuju Kesempurnaan Akhlak. Cet, V; Bandung: Mizan 1994. Minarti, Sri. Ilmu Pendidikan Islam Fakta Teoritis - Filosofis dan Aplikatif Normatif. Cet. I; Jakarta: Amzah, 2013.

Ramayulis. Metodologi Pendidikan Agama Islam. Cet.IV; Jakarta: Kalam Mulia, 2005.

Saebani, Beni Ahmad \& Abdul Hamid. Ilmu Akhlak. Bandung: CV. Pustaka Setia, 2010. 
Shaleh, Abdul Rahman dan Muhbid Abdul Wahab, Psikologi Suatu Pengantar: Dalam Persfektf Islam. Cet. II, Jakarta: Kencana 2005.

Sudarsono. Etika IslamTentang Kenakalan Remaja. Jakarta:Rineka Cipta, 2005.

Sudjana, Nana. Dasar - dasar Proses Belajar Mengajar. Cet. XII; Bandung: Sinar Baru Algensindo, 2011

Takariawan, Cahyadi. Pernik-Pernik Rumah Tangga Islami, Cet II; Solo: intermedia, 2002.

Tohirin, Psikologi Pembelajaran Pendidikan Agama Islam: Berbasis Integrasi dan Kompetensi. Ed.1. Cet.II; Jakarta: Raja Grafindo Persada, 2005.

Tohirin. Psikologi Pembelajaran Pendidikan Agama Islam, Cet.III; Jakarta: Raja Grafindo Persada, 2005.

Utami, Munandar. Kreativitas dan Keterbakatan Startegi Mewujudkan Potensi Kreatif dan Bakat. Jakarta: Gramedia Pustaka, 2002

Willis, Sofyan S., Psikologi Pendidikan, Cet.I; Bandung: Alfabeta, 2012.

Zainuddin dan Muhammad Jamhari, Al-islam Muamalah dan Akhlak. Semarang: CV Pustaka Setia, 2000.

Zuhairini, dkk. Filsafat Pendidikan Islam. Jakarta: Bumi Aksara, 2008 